\title{
Modulatory effect of Althaea officinalis L root extract on cisplatin-induced cytotoxicity and cell proliferation in A549 human lung cancer cell line
}

\author{
Yukun Zhang, Fanhua Kong, Lei Zhang and Chao Li, Runqi Zhang* \\ Department of Thorax Surgery, Taian City Central Hospital, Taian City 271000, Shandong Province, China
}

*For correspondence: Email: drzhangrunqi@hotmail.com; Tel/Fax: 0086-0538-6298489

Received: 15 April 2016

Revised accepted: 16 November 2016

\begin{abstract}
Purpose: To explore the modulatory effect of an Althaea officinalis root extract (AORE) on cisplatininduced cytotoxicity and cell proliferation in a lung cancer cell line.

Methods: Aqueous AORE was obtained from peeled and powdered roots. The effect of cisplatin on cytotoxicity and cell proliferation was studied. The cisplatin concentrations tested ranged from $0-30$ $\mathrm{mg} / \mathrm{mL}$. Cell viability and proliferation were studied using trypan blue and MTT assays, respectively. The cells were also exposed to a combination of cisplatin and the AORE.

Results: Cisplatin yielded a $50 \%$ inhibitory concentration at $25 \mathrm{mg} / \mathrm{mL}$ and exhibited a dose-dependent cell proliferation loss. Combined use of the root extract and cisplatin had significant $(R 2=0.8305)$ modulatory effects on cytotoxicity and antiproliferative activities. The best inhibitory effects were observed in cells exposed to a combination of 8 or $10 \%$ AORE and $25 \mathrm{mg} / \mathrm{mL}$ cisplatin. The optimal effect on cell proliferation was obtained using $25 \mathrm{mg} / \mathrm{mL}$ cisplatin and $10 \% \mathrm{~V} / \mathrm{v}$ AORE.

Conclusion: The enhanced activity of cisplatin in combination with AORE was more pronounced for cell proliferation than cytotoxicity, indicating that AOREs may be used to control tumor progression and metastasis.
\end{abstract}

Keywords: A549 cells, Althaea officinalis, lung cancer, cell proliferation, cell viability, cisplatin, modulatory effect

Tropical Journal of Pharmaceutical Research is indexed by Science Citation Index (SciSearch), Scopus, International Pharmaceutical Abstract, Chemical Abstracts, Embase, Index Copernicus, EBSCO, African Index Medicus, JournalSeek, Journal Citation Reports/Science Edition, Directory of Open Access Journals (DOAJ), African Journal Online, Bioline International, Open-J-Gate and Pharmacy Abstracts

\section{INTRODUCTION}

Althaea officinalis (AO), known as common marshmallow or marshmallow, belongs to the Malvaceae family within the order Malvales. This plant has perennial roots and stems that die in the autumn [1]. The Greek meaning of the generic name Althaea is "to cure" or "to heal," signifying the beneficial application of this plant, especially its perennial roots [2]. Apart from the roots, the leaves, seeds, and flowers of the plant are used in traditional Chinese medicine $[3,4]$; major therapeutic applications of $\mathrm{AO}$ roots include treating ailments of the throat, mucous membranes, digestive system, and structures of the respiratory system, including the bronchial tubes [5]. AO extracts are known to have antiinflammatory, antimicrobial, anti-tussive, hypoglycaemic, and dermatological healing effects $[6,7]$. The leaves and roots are either applied topically as a paste or consumed directly. The roots of the plant are also used as a dried powder and as a vegetable. The most common preparation of this plant is marshmallow confectioneries, while the roots of $\mathrm{AO}$ are commonly used for their health effects. 
The major phytochemicals identified in $\mathrm{AO}$ roots are mucilage with many polysaccharides, pectin, and tannins $[8,9]$. The mucilage content of $A O$ varies between seasons, with maximum and minimum amounts present in winter and summer, respectively [10]. The pharmaceutical importance of $\mathrm{AO}$ has been extensively reviewed [11].

A549 is a human non-small cell lung adenocarcinoma cell line of the basal epithelial type. Having a doubling time of $22-24 \mathrm{~h}$, this cell line is robust and well-suited for several in vitro applications.

Cisplatin is a chemotherapeutic drug used extensively for cancer therapy, and it has been the drug of choice for several in vitro research applications. Cisplatin functions by inducing apoptosis via DNA cross-linking.

The aim of this work was to determine the effect of AOR on the activity of cisplatin in A549 cells using two end points: cytotoxicity and cell proliferation.

\section{EXPERIMENTAL}

\section{Plant material collection and extraction}

Collection of the AOR extract was performed in the winter of 2013, with the roots dried and peeled. A fine powder was obtained from the peeled roots by mechanical grinding and aliquots of $1 \mathrm{~g}$ were stored at $-20^{\circ} \mathrm{C}$. A total of $1 \mathrm{~g}$ of fine powder was mixed in $10 \mathrm{~mL}$ of Milli-Q water at 4 ${ }^{\circ} \mathrm{C}$, filter-sterilized, and stored at $-20{ }^{\circ} \mathrm{C}$ before being used for the experiments. The authentication of the plant identity and classification was performed by a taxonomist, $\mathrm{Dr}$ Hu Hong of Kunming Institute of Botany, Yunnan Province, China. A voucher specimen has been preserved at South China Botanical Garden Herbarium, Chinese Academy of Sciences (IBSC) with tTaxon Id \# 20001368.

\section{Experimental design and cell cultures}

The entire study was performed in three steps, as follows: (1) ascertain the $50 \%$ inhibitory concentration $\left(\mathrm{IC}_{50}\right)$ value of cisplatin in A549 cells, (2) ascertain the effect of direct exposure to an AOR extract on A549 cells, and (3) ascertain the modulatory effect of an AOR extract on cisplatin-induced cell inhibitory effects in the selected cell line. Healthy A549 cells from $85 \%$ confluent T-25 flasks cultured in DMEM supplemented with $10 \%$ FBS were used as a seed stock for all experiments. The seeding density of the cells used was $0.17 \times 10^{6}$ cells $/ \mathrm{mL}$ in 24-well plates ( $1 \mathrm{~mL}$ cultures) and $1.0 \times 10^{5}$ cells/well in 96-well plates ( $200 \mu \mathrm{L}$ cultures). Cell viability and MTT assays were used as end points; cytotoxicity experiments were conducted in 24-well plates, and the MTT assay was performed in 96-well culture plates. For cytotoxicity assays, cells were collected along with the supernatant after mild mixing and attached cells were trypsinized, harvested, and pooled with the supernatants. Cells were washed once in medium without FBS and were analyzed for percent viability using the trypan blue assay. The MTT assay was performed on cells after the respective drug and combination (drug + AOR extract) exposures. After exposure to the drug or the drug + AOR extract, the wells of 96-well plates were filled with $10 \mu \mathrm{L}$ of MTT (stock: 10 $\mathrm{mg} / \mathrm{mL}$ ) and incubated for $4 \mathrm{~h}$. A total of $10 \mu \mathrm{L}$ of solubilization buffer containing $10 \%$ SDS and $0.01 \mathrm{~N} \mathrm{HCl}$ was added to the wells and the plates were incubated overnight at room temperature. The absorbance was measured at $550 \mathrm{~nm}$ using a microplate reader. All experiments were performed in triplicate; the average of the triplicate values were taken as the final values.

\section{Evaluation of cisplatin activity on A549 cells}

The $\mathrm{IC}_{50}$ value of cisplatin in A549 cells was determined by exposing cells to $10,15,20,25$, and $30 \mathrm{mg} / \mathrm{mL}$ cisplatin for $24 \mathrm{~h}$. Similarly, cells in the 96-well plates were exposed to the same concentrations of the drug for $24 \mathrm{~h}$ and analyzed using the MTT assay.

\section{Evaluation of exposure of AOR extract on A549 cells}

AOR extract exposure was performed in 24- and 96-well plates to explore the effects of the AOR extract on A549 cells. In addition, a $10 \%$ stock extract was added to the cell culture wells to obtain a final concentration of 2, 4, 6, 8, and 10 $\%$ of the stock. The cultures were incubated for $24 \mathrm{~h}$ and analyzed by trypan blue and MTT assays, as described above.

Determination of modulatory effect of the AOR extract on cisplatin-induced cytotoxicity in A549 cells

Cells in 24- and 96-well plates were simultaneously exposed to cisplatin at the IC50 concentration and 2, 4, 6, 8, and $10 \%$ AOR extract (as in step 2). The cultures were incubated for $24 \mathrm{~h}$ and analyzed by trypan blue and MTT assays, as described above.

Trop J Pharm Res, December 2016; 15(12): 2648 


\section{Statistical analysis}

A one-way analysis of variance was used to analyze the variables. Standard deviation was expressed as error bars and R-values in the graphs.

\section{RESULTS}

\section{Cell morphology}

Healthy cells did not show any change in morphology when exposed to the AOR extract. However, morphological changes were observed for cells exposed to cisplatin and a combination of $25 \mathrm{mg} / \mathrm{mL}$ cisplatin + $10 \% \mathrm{v} / \mathrm{v}$ AOR extract (Figure 1).

\section{Effect of cisplatin on A549 cell viability}

The viability of untreated A549 cells was $96 \%$ while the values for cisplatin at concentrations of $0,0.25,5,10,15,20,25$, and $30 \mathrm{mg} / \mathrm{mL}$ were
96, 92, 81, 72, 63, 56, 52, and $49 \%$, respectively. The $\mathrm{IC}_{50}$ value of cisplatin was close to $25 \mathrm{mg} / \mathrm{mL}$ (Figure 2a).

\section{Cytotoxicity and cell proliferation}

The absorbance value for the control was 0.73 while it was $0.64,0.61,0.58,0.52,0.47,0.32$, and 0.26 for the seven different cisplatin concentrations, respectively (Figure $2 b$ ).

\section{Cell viability after exposure to AOR extract}

There was no significant effect of direct exposure to the AOR extract on A549 cells. However, a marginal decrease in viability was observed in cells exposed to 8 and $10 \%$ AOR stock extract with $94 \%$ viability (Figure 3 ).

The MTT assay did not show any significant effect on cell proliferation, with absorbance values close to 0.72 for all concentrations.
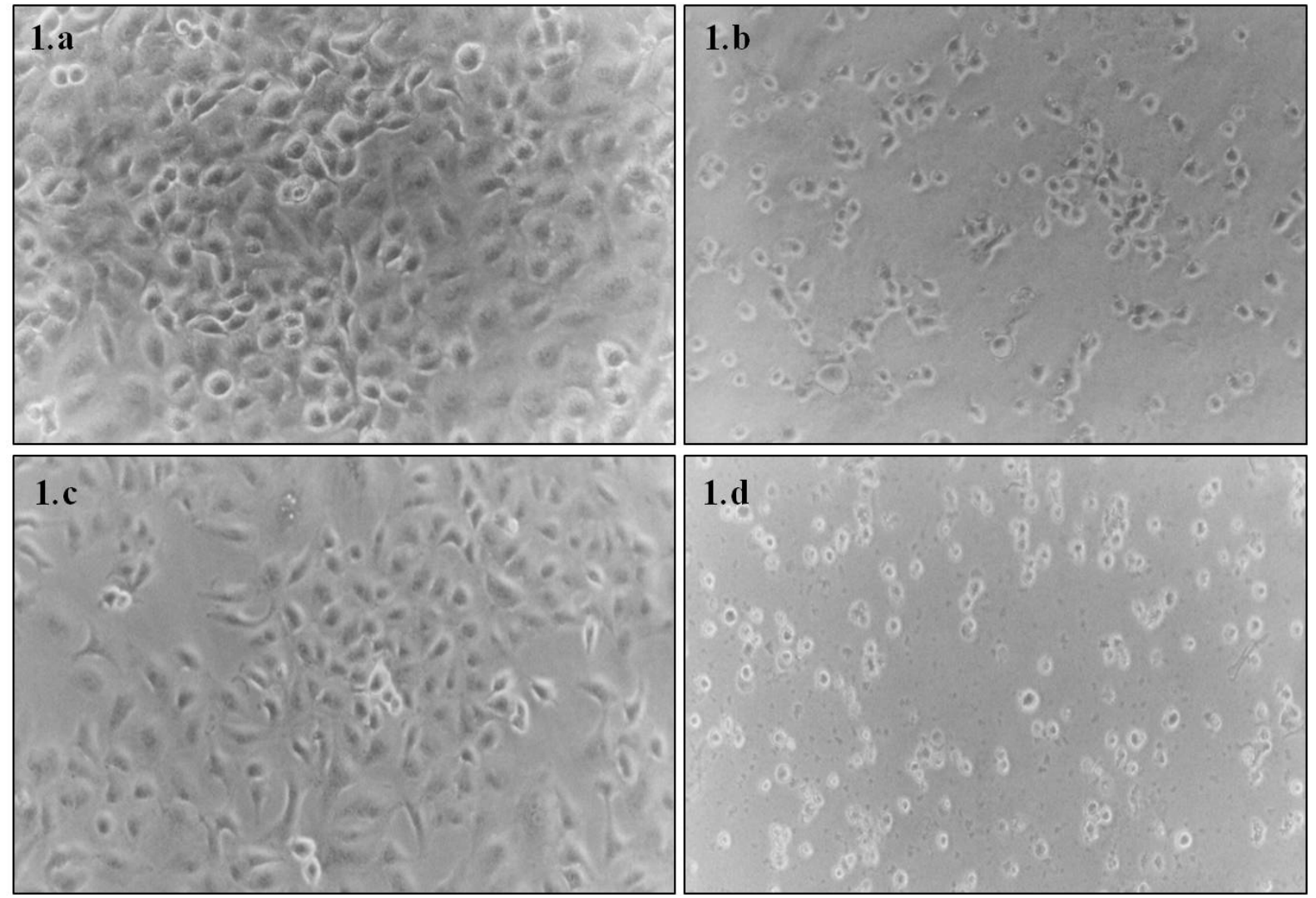

Figure 1: Panels show A549 cells in their normal healthy condition and after exposure to cisplatin, the AOR extract, or a combination of the AOR extract + cisplatin. Panels $1 \mathrm{a}$ and $\mathrm{c}$ show control cells and those exposed to the AOR extract respectively. Panel $1 \mathrm{~b}$ shows cells exposed to $30 \mathrm{mg} / \mathrm{mL}$ of cisplatin, which is close to the $\mathrm{IC}_{50}$ value. Panel 1d shows cells exposed to a combination of $25 \mathrm{mg} / \mathrm{mL}\left(\mathrm{IC}_{50}\right)$ cisplatin $+10 \%$ AOR extract, which induced a maximum inhibitory effect with minimal cell viability 



Figure 2: Panel 2a shows the $\mathrm{IC}_{50}$ value of cisplatin (approximately $27 \mathrm{mg} / \mathrm{mL}$ ). Panel $2 \mathrm{~b}$ shows the dose response of cisplatin exposure in reducing the proliferation of A549 cells

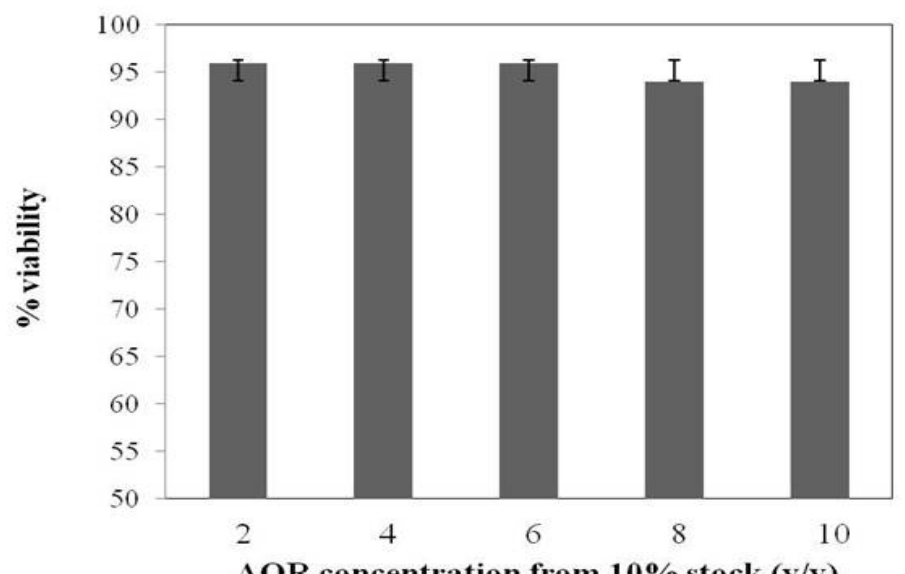

Figure 3: The AOR extract did not have any significant effect on cell viability, suggesting that the extract did not have any toxic effects on the cells

\section{Effect of AOR extract on cisplatin-induced cytotoxicity in A549 cells}

The cells exposed to $25 \mathrm{mg} / \mathrm{mL}\left(\mathrm{IC}_{50}\right)$ cisplatin and $2,4,6,8$, and $10 \%$ AO stock extract produced viability values of $51,51,41,41$, and $39 \%$, respectively. While the 2 and $4 \%$ AOR stock extracts did not have any significant cytotoxicity-enhancing effect, there was a significant increase in cytotoxicity (increased $\mathrm{IC}_{50}$

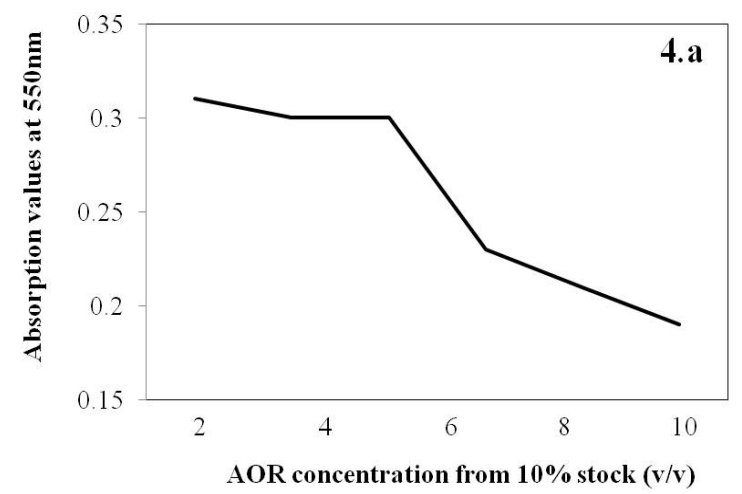

value of cisplatin) in cultures exposed to 8 and $10 \%$ AOR stock extract (Figures 4 and 5).

\section{Cell proliferation}

The absorbance values for cells exposed to 25 $\mathrm{mg} / \mathrm{mL}$ cisplatin and $0,2,4,6,8$, and $10 \%$ AOR stock extract were $0.31,0.3,0.3,0.23,0.21$, and 0.19 , respectively (Figure 6).

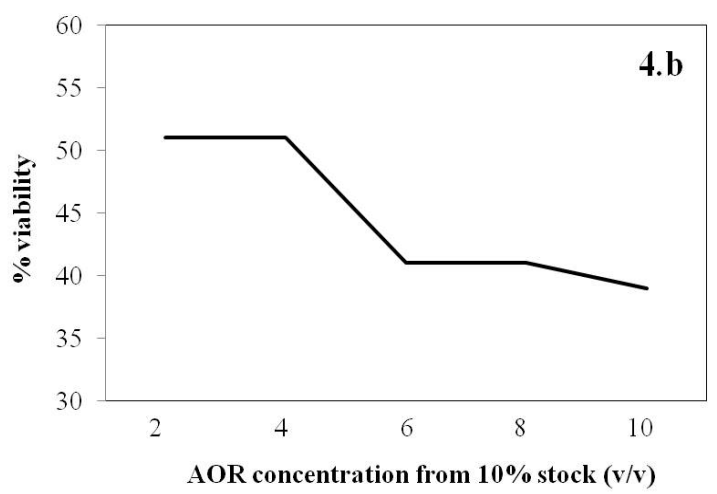

Figure 4: Effect of AOR extract on cisplatin-induced anti-proliferation and toxicity in A549 cells. Panels 4a and b show a synergistic effect on proliferation and toxicity, respectively. The $\mathrm{IC}_{50}$ values of cisplatin decreased in the presence of the AOR extract compared to the $\mathrm{IC}_{50}$ of cisplatin exposure in isolation 


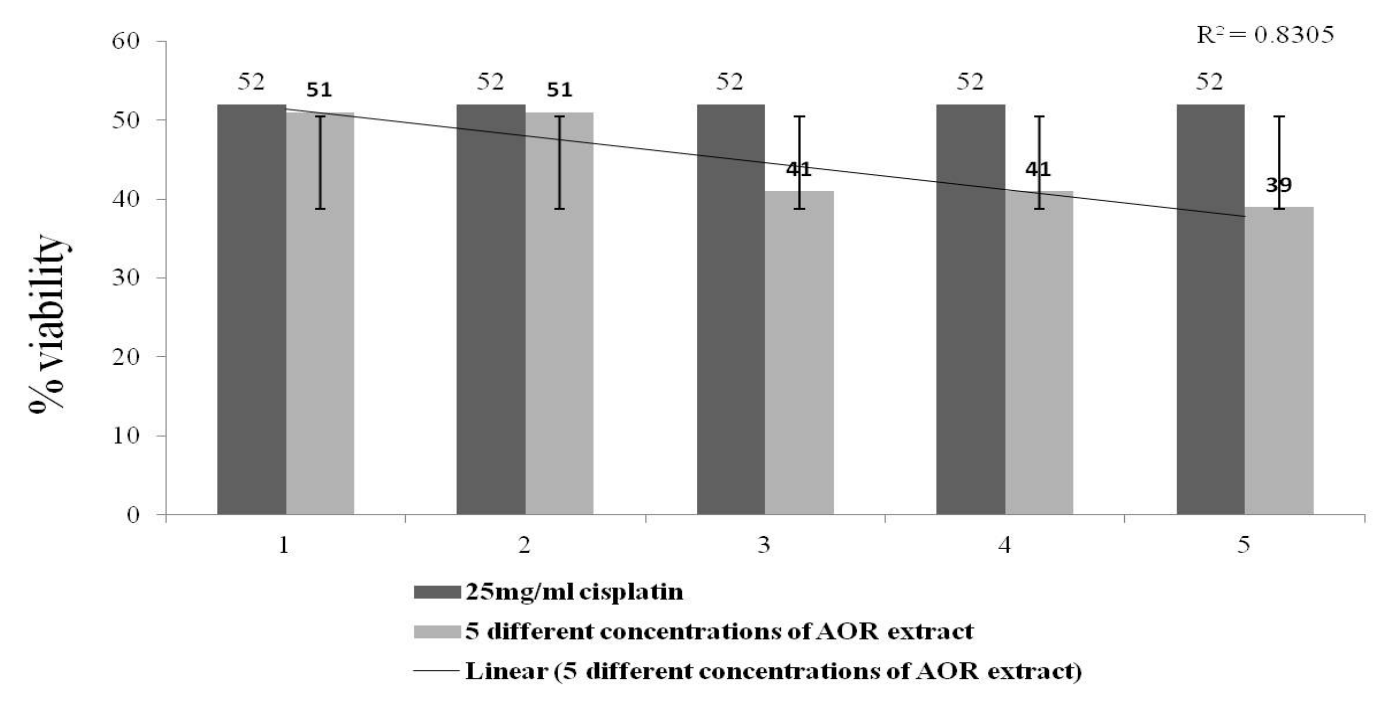

Figure 5: Supplementation with 8 or $10 \% \mathrm{v} / \mathrm{v}$ of the AOR extract along with cisplatin at the $\mathrm{IC}_{50}$ concentration (25 $\mathrm{mg} / \mathrm{mL}$ ) increased cytotoxicity significantly. A standard deviation of 41 and 39 for AOR extract supplementation with 6,8 , and $10 \% \mathrm{v} / \mathrm{v}$ was obtained, indicative of a positive modulatory effect of the extract on cisplatin-induced effects in the cell line

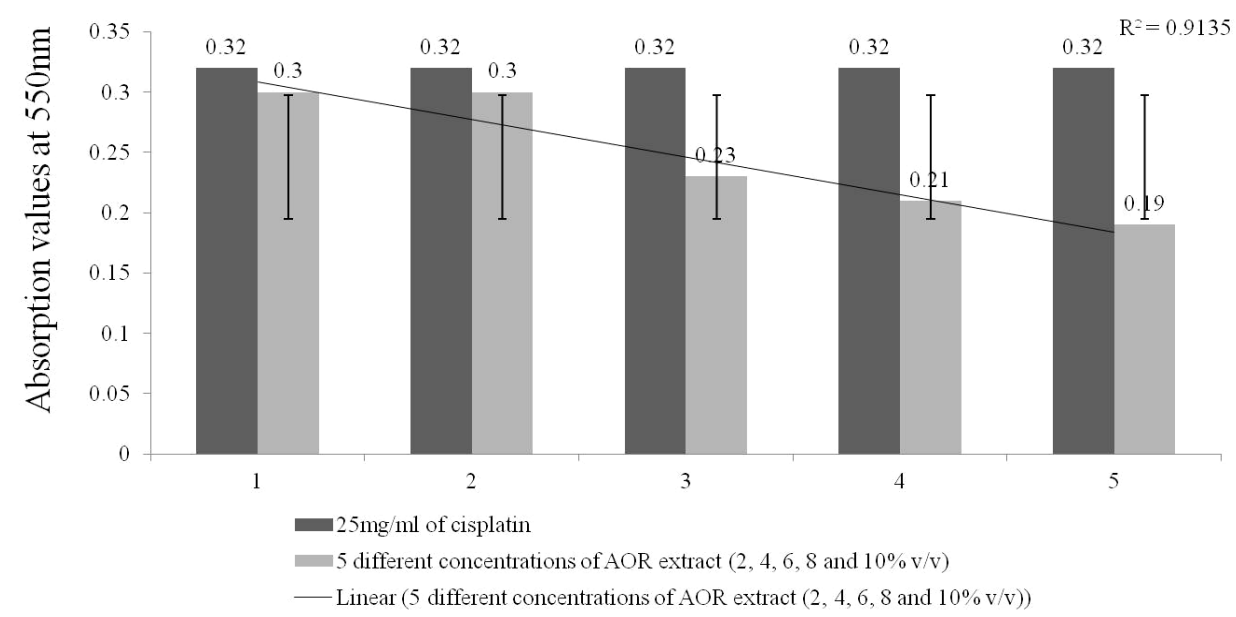

Figure 6: The AOR extract had significant synergistic effects at 8 and $10 \% \mathrm{v} / \mathrm{v}$ on cisplatin-induced antiproliferative activity. The standard deviation for AOR extract supplementation at 6,8 , and $10 \% \mathrm{v} / \mathrm{v}$ was 0.23 , 0.21 , and 0.19 respectively, which indicates significant anti-proliferative activity for the applied combination

\section{DISCUSSION}

The cell line (A549) and drug (cisplatin) used in this study are considered useful materials based on several previous studies. AOR extracts are also commonly used in traditional medicine; the past decade has seen a growing number of scientific reports of studies performed systematically using AOR extracts. The AOR extract in this study was used in combination with cisplatin to study its modulatory effects on two parameters: cytotoxicity and anti-proliferation. While cytotoxicity is an effect of immediate and direct consequence, cell proliferation involves a sequence of events. However, both parameters have relevance to cancer research in terms of killing cancer cells and limiting metastasis. The
AOR extract did not induce changes in the morphology, viability, or proliferation of A549 cells, suggesting that it is safe for cells. The extract had marked modulatory effects on cisplatin-induced toxicity and an anti-proliferative effect at 8 and $10 \% \mathrm{v} / \mathrm{v}$. The synergistic effect was significant; it induced marked morphologic changes with a reciprocal loss in viability. A combination of $25 \mathrm{mg} / \mathrm{mL}$ cisplatin $+10 \% \mathrm{v} / \mathrm{v}$ AOR extract induced more pronounced antiproliferative activity compared to cisplatininduced cytotoxicity.

\section{CONCLUSION}

The findings of this study indicate the usefulness of AOR extract in modulating the effect of 
cisplatin in A549 cells in terms of cytotoxicity and cell proliferation. The modulatory effect on cell proliferation was greater than the effect on cytotoxicity, demonstrating that AOR extract is a potential anti-cancer agent.

\section{DECLARATIONS}

\section{Acknowledgement}

The authors thank the managers of the affiliated departments and hospitals for their support.

\section{Conflict of Interest}

No conflict of interest associated with this work.

\section{Contribution of Authors}

The authors declare that this work was done by the authors named in this article and all liabilities pertaining to claims relating to the content of this article will be borne by them.

\section{Open Access}

This is an Open Access article that uses a funding model which does not charge readers or their institutions for access and distributed under the terms of the Creative Commons Attribution License (http://creativecommons.org/licenses/by 14.0) and the Budapest Open Access Initiative (http://www.budapestopenaccessinitiative.org/rea d), which permit unrestricted use, distribution, and reproduction in any medium, provided the original work is properly credited.

\section{REFERENCES}

1. Gualtiero S. In: Stanley Schuler (Ed): Simon \& Schuster's Guide to Herbs and Spices. Simon \& Schuster, Inc., NY, USA, 2008. (ISBN 0-671-73489-X).

2. Cavero R. Medicinal plants used for respiratory affections in Navarra and their pharmacological validation. $J$ Ethnopharmacol 2014; 158(A): 216-220.

3. Hage-Sleiman $R$, Mroueh M, Daher CF. Pharmacological evaluation of aqueous extract of Althaea officinalis flower grown in Lebanon. Pharma Biol 2011; 49(3): 327-333.

4. Rani S, Khan SA, Ali M. Phytochemical investigation of the seeds of Althea officinalis L. Nat Product Res 2010; 24(14): 1358-1364.

5. Beaune A, and Balea, T. Anti-inflammatory experimental properties of marshmallow: Its potentiating action on the local effects of corticoids. Therapie 1966; 21(2): 341ר347.

6. Bone K. Marshmallow soothes cough. $\mathrm{Br} J$ Phytother 1993; 3(2): 93-95.

7. Piovano PB, Mazzocchi S. Clinical trial of a steroid derivative (9-alpha-fluoro-prednisolone-21-acetate) in association with aqueous extract of althea in the dermatological field. G Ital Dermatol Minerva Dermatol 1970; 45(4): 279-286.

8. Gudej J. Flavonoids, phenolic acids and coumarins from the roots of Althaea officinalis. Planta Med 1991; 57: 284-285.

9. Franz G, Chladek M. Comparative studies on the composition of crude mucus from crossbred descendants of Althaea officinalis L. and Althaea armeniaca Ten. Pharmazie 1973; 28(2): 128-129.

10. Wichtl M. Herbal drugs and phytopharmaceuticals. In: Bisset NG (Ed.). A handbook for practice on a scientific basis. Medpharm Scientific Publishers, Germany, 1994; pp 351-352.

11. Ali Esmail Al-Snafi. Pharmaceutical importance of Althaea officinalis and Althaea rosea: $A$ Review. Int $J$ Pharm Tech Res 2013; 5(3): 1378-1385. 